\title{
Impact of Psycho-Spiritual Intervention on Psychological Well- Being of Congenital and Acquired Visually Impaired Adolescents
}

\author{
Anamika Mishra $^{1}$, Dr. Anuradha Kotnala ${ }^{2}$
}

\section{ABSTRACT}

The present study was designed to study the impact of psycho-spiritual package on psychological well-being of acquired and congenital visually impaired adolescents in the age group of 12 to 18 . The sample consisted of 100 visually impaired adolescents (50 congenital and 50 acquired visually impaired adolescents) divided into experimental and control group of 50 each. Hindi adaptation of Ryff's psychological well being scale was used in the study. The results show that psycho-spiritual package increases the psychological well being of both the congenital and acquired visually impaired adolescents.

Keywords: Psychological Well-Being, Psycho-Spiritual Intervention, Acquired Visually Impaired Adolescents And Congenital Visually Impaired Adolescents.

The best and most beautiful things in the world cannot be seen or even touched. They must be felt with the heart. Imagine the life one has to live without seeing the beauty of rising sun, beauty of blooming flowers and even unable to see the face of his mother. So, eyes are the most precious organ in the human body used to view the world, so one has to face innumerable difficulties in the absence of vision. Various problems that the visually impaired people face are problems in orientation and mobility, problems in conversation, problems in social contact, personality problems, psychological problems etc. Blindness may therefore create formidable social and psychological problems for individual. Visual impairment is such a disability that affects entire personality and psychological well being of a person.

Unlike sighted adolescents, blind adolescents have a harder time with finding independence. Adolescence is the stage of human development that bring about, among other outcomes, the deepest identity crisis, during which the perception of self is challenged to a point in which a whole new personal identity starts to develop.

\footnotetext{
${ }^{1}$ Research Scholar, Dev Sanskriti University, Haridwar, India

${ }^{2}$ Associate Professor, Dev Sanskriti University, Haridwar, India

*Responding Author

(C) 2016, A Mishra, A Kotnala; licensee IJIP. This is an Open Access Research distributed under the terms of the Creative Commons Attribution License (http://creativecommons.org/licenses/by/2.0), which permits unrestricted use, distribution, and reproduction in any Medium, provided the original work is properly cited.
} 


\section{Impact of Psycho-Spiritual Intervention on Psychological-Well-Being of Congenital and Acquired Visually Impaired Adolescents}

They have to depend more on others to get where they want to go. Sighted adolescents can go off anywhere. It is important for visually impaired adolescents to feel independent. With the feeling of autonomy or independence come a higher self esteem and a better sense of identity. Blind adolescents those have high self esteem and a strong sense of identity have an easier time adapting to their environments than those with low self esteem and weaker sense of identity.

It is important for blind adolescents to have positive peer relationships (positive relations with others). A positive peer relationship helps to improve a blind adolescent's self-image and selfesteem. Peers also give them a sense of being a "normal" adolescent. Many blind adolescents though find it difficult to socialize with their sighted peers. This is because in adolescents those that are different from the normal are not always accepted in the sighted peer groups.

Visual impairment refers to condition characterized by complete loss of vision either congenital or acquired. Many children either born visually impaired or develop visual impairment in the early years of their lives. Who they are visually impaired by born is called 'congenital blind' and who develop visually impairment in the early years of their lives are 'acquired blind'. Whether vision loss is by birth or acquired, it is cause for great stress and anxiety, often leading to physical, emotional, and social limitations.

Psychological well being is about lives going well and the combination of feeling good and effectively. Sustainable well being does not requires individuals to feel good all the time ; the experience of painful emotions(disappointment, failure, grief etc) is normal part of life , and being able to manage these negative or painful emotions is essential for long term well being. Carol Ryff (1989) believes well-being can be described through a number of components: Selfacceptance, Personal growth, Purpose in life, Environmental mastery, Autonomy and Positive relations with others. For each area, consider: what does this mean day to day? How much are we 'doing' it in our life, today? How could we increase it tomorrow?

Psycho-spiritual intervention is technique involves psychological technique and spiritual techniques for the treatment of psychological problems. For enhancing the psychological wellbeing of visually impaired adolescents researcher developed a psycho-spiritual package. This package consists of Amritvani (Motivating messages of Pt. Shri Ram Sharma Acharya,1981), So-ham sadhana and group counseling. This package was 60 minute program for 30 days.

In amritvani researcher choose those motivating messages which are related to the components of the dependent variable psychological well-being viz; self-acceptance, personal growth, purpose in life, environmental mastery, autonomy, and positive relation with others. It was given to the facilitated group every day for five minutes. 
Soham sadhna is a combination of pranayam and meditation. According to Swami Satyanand (2006): "It is said that through pranayam in soham sadhna you enter the land of meditation". Literally meaning of Soham is 'I am that' i.e. I am a devotee of that supreme once, and he is my lord (omnipresent God). Soham sadhna was 25 minute program of every day for the facilitated group.

Group counseling is a form of therapy where a small group client meets regularly to talk, interact and discuss problem with each other. In this research group counseling was an opportunity to visually impaired adolescents to discuss their problems together and also had the opportunity to seek their ideas of solution during the alternative brain-storming stage. It was 30 minute program of every day.

Studies have been done in many fields related to adolescents, but researches related to visually impaired adolescents are rare and there is a need to understand the psychological well being of visually impaired adolescents (congenital and acquired visually impaired adolescents) and suggest some ways to improve it. Several studies have shown that the practice of spiritual techniques such as meditation, visualization, have a definite role in the promotion of positive health including psychological well being. In the present study the researcher has attempted to investigate the "Impact of psycho-spiritual intervention on psychological well- being of visually impaired adolescents”.

\section{Hypotheses:}

1. Psycho-spiritual intervention increases the psychological well-being of congenital visually impaired adolescents.

2. Psycho-spiritual intervention increases the psychological well-being of acquired visually impaired adolescents.

\section{Variables:}

The variable for the study have been categorized as follows-

Independent Variable- Psycho-spiritual intervention

Dependent Variable- Psychological well-being of congenital and acquired visually impaired adolescents.

\section{Research Design:}

The study employed control group design.

\section{Sample:}

The sample consisted of 100 male visually impaired adolescents in the age group of 12 to 18(50 acquired and 50 congenital visually impaired adolescents). They were divided into two groups 


\section{Impact of Psycho-Spiritual Intervention on Psychological-Well-Being of Congenital and Acquired Visually Impaired Adolescents}

viz experimental and control groups and matched in regard to education, socioeconomic status and level of psychological well-being.

\section{Tools:}

Hindi adaptation of Ryff's(1989) psychological well-being done by Dr S. N. Rai and Mrs. Deepika Gupta (2006), was used for the assessment of psychological well being of visually impaired adolescents.

\section{Procedure:}

In this empirical study a sample of 100 visually impaired adolescents (50 congenital and 50 acquired visually impaired adolescents) was taken from Ajranand Andh Vidyalaya, Haridwar. These subjects were randomly placed in two groups, 50 in experimental and 50 in control group. Dr S.N.Rai's hindi adaptation scale of carol ryff's psychological well-being scale was administered upon both the groups and the test was administered orally and individually. After matching the both the groups researcher applied psycho -spiritual intervention on facilitated group. Psycho- spiritual intervention consists of amritvani (Motivating thoughts), Soaham sadhna and group counseling. This package was 60 minutes programme that continued for 30 days. After 30 days the psychological well-being was measured of both the groups. The data were analyzed using 't' test.

\section{RESULT}

\section{Table: 1}

\begin{tabular}{|c|c|c|c|c|c|c|}
\hline $\begin{array}{c}\text { Groups of } \\
\text { congenital } \\
\text { visually impaired } \\
\text { adolescents }\end{array}$ & $\begin{array}{l}\text { Psychological } \\
\text { Well-being }\end{array}$ & N & Means & SD & SEd & t-value \\
\hline \multirow{2}{*}{ Experimental } & Pre & 25 & 158.42 & 16.13 & & \\
\cline { 2 - 5 } Control & Post & 25 & 188.62 & 12.88 & \multirow{2}{*}{3.71} & 8.26 \\
\cline { 2 - 5 } & Pre & 25 & 158.12 & 15.48 & \\
\hline
\end{tabular}

$\mathrm{p}<0.01$

\section{Result Table: 2}

\begin{tabular}{|l|c|l|l|l|l|l|}
\hline $\begin{array}{l}\text { Groups of } \\
\text { acquired visually } \\
\text { impaired } \\
\text { adolescents }\end{array}$ & $\begin{array}{l}\text { Psychological } \\
\text { Well-being }\end{array}$ & N & Means & SD & SEd & t-value \\
\cline { 1 - 5 } Experimental & Pre & 25 & 157.21 & 13.33 & & \\
\cline { 1 - 5 } Control & Post & 25 & 182.13 & 12.66 & \multirow{2}{*}{3.14} & \multirow{2}{*}{7.40} \\
\cline { 2 - 5 } & Pre & 25 & 157.96 & 9.14 & \\
\hline
\end{tabular}

$\mathrm{p}<0.01$ 


\section{DISCUSSION}

Results of the present study lead to the acceptance of both the hypotheses that there is a significant effect of Psycho-spiritual intervention on psychological well-being of congenital and acquired visually impaired adolescents. The higher mean score of facilitated group on psychological well-being suggests that the students who participated regularly in psycho-spiritual intervention program are happier and mentally healthy in comparison to control group.

After comparing of means of both (congenital and acquired visually impaired adolescents group) the experimental group researcher finds that the impact of psycho-spiritual intervention is slightly higher in congenital visually impaired adolescents in comparison to acquired visually impaired adolescents. Thus we can conclude psycho-spiritual intervention affects the human personality and enhances the hidden quality of visually impaired adolescents.

Results are consistent with the previous research finding that the specialized counseling services can be helpful in facilitating the well being among the individuals visual disability. Ishawar and Nishad (2010) found that the adolescent's student who practiced yogic concentrative meditation experienced gains to both psychological well-being and leadership skills. In another research Singh, J.P. (2007) found that proper training and rehabilitation efforts can do much to help the blind adapt effectively to living with loss of sight. Betal C. (2005) found that those who are daily practicing meditation have better health in comparison to those who are not practicing.

\section{CONCLUSION}

The result of present study reveals that the psycho-spiritual intervention improves the psychological well being of visually impaired adolescents. It affects the autonomy, environmental mastery, positive relation with others, self acceptance, personal growth and purpose in life. All these aspects affect the interpersonal and social behavior of an individual. Hence, it can be concluded that the psycho-spiritual package is beneficial for visually impaired adolescents and strengthen the positive aspects of them and also helps in developing the society.

\section{Acknowledgments}

The author appreciates all those who participated in the study and helped to facilitate the research process.

\section{Conflict of Interests}

The author declared no conflict of interests.

\section{REFERENCES}

Acharya, Pt. S. S. (1981). Hamsa yoga: The elixir of self rehabilitation .Yug nirman yojna press.

Beaty, L. A. (1992). Adolescent self perception as a function of vision loss. Adolescence, 27,707-714. 


\section{Impact of Psycho-Spiritual Intervention on Psychological-Well-Being of Congenital and Acquired Visually Impaired Adolescents}

Betal, C. (Jan, 2005). Effect of transcendental meditation on home, health, social and emotional adjustment of degree student. Yogamimamsa, vol.xxxvi. no.4:228-241.

Davidson, R. (1975). Psycho-social dynamics of blind students: concept publishing company PVT. LTD. New Delhi-110059, (pp.53-54).

Ishwar, B., \& Nishad, I. (2010). Impact of Manomay kosh-sadhna on adolescents mental health and leadership capacity. International journal of education and allied sciences, 2(2), 101108.

Rai, S. N. (2006). Hindi adaptation of Ryff's psychological well being scale.

Ryff, (1989). Journal of personality and social psychology, 57, 1069-1081.

Smith, C. (1975). Meditation as psychotherapy. Psychological bulletin, 82(4).

Sunilkumari, S. (2009). Problems and coping strategies of Blind children. Nightingale Nursing Times, 5(7):54-6.

Swami, S. S. (2006). Sure ways to self realization. Yoga publication trust, Munger, Bihar, India, (pp-105-107).

How to cite this article: A Mishra, A Kotnala (2016), Impact of Psycho-Spiritual Intervention on Psychological-Well-Being of Congenital and Acquired Visually Impaired Adolescents, International Journal of Indian Psychology, Volume 3, Issue 4, No. 74, ISSN:2348-5396 (e), ISSN:2349-3429 (p), DIP:18.01.028/20160304, ISBN:978-1-365-46362-4 